CLINICAL STUDY

\title{
Dopamine agonist therapy of clinically non-functioning pituitary macroadenomas. Is there a role for ${ }^{123}$ I-epidepride dopamine $\mathrm{D} 2$ receptor imaging?
}

\author{
Wouter W de Herder ${ }^{1}$, Ambroos E M Reijs ${ }^{2}$, Richard A Feelders ${ }^{1}$, Maarten O van Aken ${ }^{1}$, Eric P Krenning ${ }^{2}$, \\ Hervé L J Tanghe ${ }^{3}$, Aart-Jan van der Lely ${ }^{1}$ and Dik J Kwekkeboom ${ }^{2}$ \\ Departments of ${ }^{1}$ Internal Medicine, Section of Endocrinology, ${ }^{2}$ Nuclear Medicine and ${ }^{3}$ Radiology Erasmus MC, S Gravendijkwal 230,3015 CE Rotterdam, \\ The Netherlands \\ (Correspondence should be addressed to WW de Herder; Email: w.w.deherder@erasmusmc.nl)
}

\begin{abstract}
Objective: Clinically non-functioning pituitary adenomas (NFPAs) can express functional dopamine D2 receptors. Therapy with dopamine (DA) agonists may result in a NFPA size reduction. However, DA agonist-sensitive and -resistant NFPAs are clinically indistinguishable. We have studied the correlation between in vivo imaging of D2 receptors using ${ }^{123}$ I-epidepride and the radiological response of NFPA to DA in 18 patients.

Methods: Patients were treated with either cabergoline (1-2 mg/week) or quinagolide (150-300 $\mu \mathrm{g} /$ day) for a mean period of 89.7 months (range, 34-187 months).

Results: Pituitary uptake of ${ }^{123}$ I-epidepride varied from slight uptake classified as grade 0 to very high classified as grade 3. Grade 0 uptake was found in four patients; grade 1 in three; grade 2 in ten, and grade 3 in one. NFPA stabilization or shrinkage with DA agonist therapy showed no significant difference between grade 0, 1, and 2 tumors (mean tumor stabilization or shrinkage: 31, 30, and 36\% respectively). However, when we considered a decrease in tumor size ranging from 0 to $20 \%$ as tumor stabilization and $>20 \%$ decrease in tumor size as true shrinkage, one out of four NFPAs with grade 1 uptake, two out of three with grade 1 uptake, and eight out of ten with grade 2 uptake showed tumor shrinkage.

Conclusion: In conclusion, there is limited clinical usefulness of dopamine D2 receptor imaging for predicting the clinical efficacy of DA agonist in selected patients with NFPAs. DA agonist therapy in NFPAs can result in tumor stabilization and shrinkage.
\end{abstract}

European Journal of Endocrinology 155 717-723

\section{Introduction}

Clinically non-functioning pituitary adenomas (NFPAs) are the most prevalent pituitary macroadenomas (1-3). A specific clinical syndrome related to hormonal hypersecretion is generally absent (1-3). Therefore, most patients present late in the course of their disease, when the tumor causes mass-related signs and symptoms (1-3). Furthermore, some NFPAs present as pituitary incidentalomas (1-3). Pituitary surgery is the first line of treatment, but is generally not curative in majority of the patients (1-6). Radiotherapy is the only modality shown to be effective in the prevention of residual tumor growth (7-9). The use of dopamine (DA) agonists has been previously explored as a treatment alternative for NFPA (10-25). Greenman and co-workers have shown that postoperative DA treatment resulted in a decrease or stabilization of tumor mass in $90 \%$ of patients in contrast to 2 and 5 years re-growth rates of 30 and $70 \%$ in untreated patients respectively (26). In $61 \%$ of patients with tumor remnant growth during the course of routine follow-up, growth stabilized or decreased with this therapy (26). In contrast, tumor size remained stable only in $38 \%$ and increased in the remaining $62 \%$ of untreated subjects (26). In another study, Pivonello and co-workers have shown significant tumor shrinkage in five out of nine NFPA patients treated with the DA agonist cabergoline for 12 months (27). The more prominent response was attained in patients whose tumors expressed the dopamine 2 receptor (D2R) short isoform (27). Several groups, including our own, have shown that D2-receptor imaging in pituitary adenomas is possible with single-photon emission computed tomography (SPECT) using ${ }^{123} \mathrm{I}-\mathrm{S}-(-)-\mathrm{N}$-[(1-ethyl-2-pyrrolidinyl)methyl]-2-hydroxy-3-iodo-6-methoxybenzamide $\left({ }^{123}\right.$ I-IBZM $)$ or the substituted benzamide epidepride, (S)- $\mathrm{N}$-[(1-ethyl-2-pyrrolidinyl) methyl]-5-iodo-2, 3-dimethoxybenzamide ( ${ }^{123}$ I-epidepride) $(28-35)$. We have previously demonstrated the superiority of ${ }^{123} \mathrm{I}-$ epidepride over ${ }^{123}$ I-IBZM (31). In a series of ten patients with NFPA, the clinical usefulness of ${ }^{123}$ I-IBZM scintigraphy for predicting tumor response to DA agonists could be demonstrated in two with high tumor uptake of the 
radioligand (34). Therefore, we studied the correlation between in vivo imaging of $\mathrm{D} 2$ receptors using ${ }^{123} \mathrm{I}-$ epidepride and the response of NFPA to long-term DA agonist therapy, as evaluated by magnetic resonance imaging (MRI).

\section{Design, materials and methods}

\section{Subjects}

A total of 85 selected patients ( 34 women, 51 men) underwent scintigraphy with ${ }^{123}$ I-epidepride in our center (see Table 1). Eighteen patients ( 6 women, 12 men; mean age, 66 years; range, $32-86$ years) with NFPA were treated with DA agonists (Table 2). These patients had neither visual field defects nor decrease of visual acuity and ophtalmoplegia. A subgroup of these patients had significant co-morbidity, relative contraindications for anesthesia, or refused surgery. The remaining 36 NFPA patients had visual field defects or decreased visual acuity necessitating surgery or refused to participate in a trial with a dopamine agonist. The diagnosis of NFPA was based on the detection of a pituitary macroadenoma (remnant) on MRI, the absence of a characteristic clinical syndrome apart from hypopituitarism (in 13 patients; Table 2) and basal low to elevated serum luteinizing hormone, follicle-stimulating hormone, or glycoprotein hormone $\alpha$-subunit levels. A slightly elevated serum prolactin (PRL) $(<100 \mu \mathrm{g} / \mathrm{l}$; $3000 \mathrm{mU} / \mathrm{l})$, which was not in agreement with tumor size was interpreted as resulting from pituitary-hypothalamic disconnection. In these patients, no elevations of serum thyroid-stimulating hormone, free thyroxine, adrenocorticotrophic hormone, morning cortisol, insulin-like growth factor-I (IGF-I), or IGF-binding protein (IGFBP)-3 levels were found. None of the patients had signs or symptoms of compression of optic chiasm, nor ophtalmoplegia. Five patients had undergone transsphenoidal surgery prior to the start of therapy (patients 6, 10, 11, 14, and 18 in Table 2) and one was operated after initiation of DA agonist therapy (patient 5 in Table 2, see later). As a result, the diagnosis of NFPA could be confirmed by immunohistology on tumor specimen obtained during surgery in six patients. None of the patients underwent external pituitary radiotherapy. Patients were treated with quinagolide (150-300 $\mu \mathrm{g} /$ day) and cabergoline (1-2 mg/week) was preferentially used after it became registered in The Netherlands. Both drugs were titrated up to a maximum dose of $300 \mu \mathrm{g} /$ day quinagolide, or $2 \mathrm{mg} /$ week cabergoline, but some patients had to be treated with lower doses because of dosedependent side effects (like orthostasis and nausea). There was no placebo arm. Hypopituitarism was appropriately treated. No subject was receiving medications known to interfere with dopamine metabolism or uptake. All patients gave informed consent to participate in the study, which was approved by the hospital ethics committee (Figs 1-3).

\section{Imaging}

Pituitary SPECT studies with ${ }^{123}$ I-epidepride were performed as previously described (31). SPECT images of the head were obtained using a three-headed camera (Prism 3000 XP, Picker Int., Cleveland, Ohio, USA), equipped with a medium energy collimator. The pulse height analyzer window was centered over the energy peak $(159 \mathrm{keV})$ with a window width of $20 \% .{ }^{123} \mathrm{I}-$ epidepride was obtained from Dr Angelberger, Österreichisches Forschungszentrum Seibersdorf GmbH, Seibersdorf, Austria. The synthesis of ${ }^{123}$ I-epidepride has been previously described (29). ${ }^{123}$ I-epidepride (111$185 \mathrm{MBq}$ ) was administered intravenously and images were obtained after $3 \mathrm{~h}$. Acquisition parameters were 1 scan, 36 s/frame, 120 projections, 360 degrees, $64 \times 64$ matrix (29). Before reconstruction, a Metz filter was applied. Scintigrams were assessed by two investigators (WW de Herder and DJ Kwekkeboom) without previous

Table $1{ }^{123}$-epidepride scintigraphy in 85 patients with pituitary lesions.

\begin{tabular}{|c|c|c|c|c|c|}
\hline \multirow[b]{2}{*}{ Tumor } & \multicolumn{4}{|c|}{${ }^{123}$ |-epidepride scintigraphy uptake grade } & \multirow[b]{2}{*}{$n$} \\
\hline & 0 & 1 & 2 & 3 & \\
\hline Microprolactinoma & 3 & - & - & - & 3 \\
\hline Macroprolactinoma & - & 6 & 2 & 2 & 10 \\
\hline Somatotroph macroadenoma & 1 & 3 & 0 & 0 & 4 \\
\hline NFPA & 17 & 12 & 18 & 7 & 54 \\
\hline Silent corticotroph macroadenoma & - & 1 & 2 & - & 3 \\
\hline Rathke's cleft cyst & 2 & - & - & - & 2 \\
\hline Craniopharyngioma & 1 & - & - & - & 1 \\
\hline Metastatic prostate carcinoma & 1 & - & - & - & 1 \\
\hline Meningioma & 1 & - & - & - & 1 \\
\hline Chordoma & 1 & - & - & - & 1 \\
\hline Scar tissue & 1 & - & - & - & 1 \\
\hline \multicolumn{5}{|c|}{ Malignant prolactinoma (scan-positive metastases: 1 ) } & 2 \\
\hline \multicolumn{5}{|c|}{ Malignant corticotroph macroadenoma (scan-positive metastases: 1 ) } & 2 \\
\hline \multicolumn{5}{|c|}{ Total } & 85 \\
\hline
\end{tabular}

NEPA, non-functioning pituitary adenoma. 
Table 2 Dopamine agonist therapy in 18 patients with clinically nonfunctioning pituitary macroadenomas who have also undergone ${ }^{123}$ I-epidepride scintigraphy.

\begin{tabular}{|c|c|c|c|c|c|c|c|c|c|}
\hline $\begin{array}{l}\text { Patient } \\
\text { no. }\end{array}$ & Sex & $\begin{array}{c}\text { Age at } \\
\text { baseline }\end{array}$ & $\begin{array}{l}{ }^{123} \text { I-epidepride } \\
\text { Scan }\end{array}$ & $\begin{array}{c}\text { Hypo- } \\
\text { pituitarism }\end{array}$ & Drug & Dose & $\begin{array}{l}\text { Duration } \\
\text { of therapy } \\
\text { (months) }\end{array}$ & $\begin{array}{c}\text { Tumor } \\
\text { volume } \\
\left(\mathrm{mm}^{3}\right)\end{array}$ & $\%$ shrinkage \\
\hline 1 & $M$ & 68 & 0 & Yes & Quinagolide & $300 \mu \mathrm{g} /$ day & 163 & 23085 & 6 \\
\hline 2 & $\mathrm{M}$ & 62 & 0 & Yes & Quinagolide & $300 \mu \mathrm{g} / \mathrm{day}$ & 158 & 46637 & 99 \\
\hline 3 & $\mathrm{M}$ & 71 & 0 & Yes & Quinagolide & $150 \mu \mathrm{g} /$ day & 84 & 17149 & 18 \\
\hline 4 & $\mathrm{~F}$ & 52 & 0 & No & Quinagolide & $150 \mu \mathrm{g} /$ day & 68 & 5081 & 0 \\
\hline 5 & $\mathrm{M}$ & 79 & 1 & No & Cabergoline & $1 \mathrm{mg} /$ week & 57 & 24417 & 5 \\
\hline 6 & $\mathrm{~F}$ & 65 & 1 & Yes & Quinagolide & $300 \mu \mathrm{g} /$ day & 110 & 27231 & 58 \\
\hline 7 & $\mathrm{~F}$ & 66 & 1 & Yes & Quinagolide & $300 \mu \mathrm{g} / \mathrm{day}$ & 84 & 904320 & 27 \\
\hline 8 & M & 75 & 2 & Yes & Quinagolide & $300 \mu \mathrm{g} / \mathrm{day}$ & 34 & 76451 & 27 \\
\hline 9 & $\mathrm{~F}$ & 86 & 2 & Yes & Quinagolide & $300 \mu \mathrm{g} /$ day & 48 & 73585 & 25 \\
\hline 10 & M & 54 & 2 & Yes & Cabergoline & $1 \mathrm{mg} / \mathrm{week}$ & 34 & 91906 & 32 \\
\hline 11 & $\mathrm{M}$ & 32 & 2 & No & Quinagolide & $300 \mu \mathrm{g} /$ day & 96 & 407513 & 74 \\
\hline 12 & $\mathrm{M}$ & 75 & 2 & Yes & Quinagolide & $150 \mu \mathrm{g} / \mathrm{day}$ & 39 & 19383 & 27 \\
\hline 13 & M & 59 & 2 & Yes & Cabergoline & $1 \mathrm{mg} / \mathrm{week}$ & 84 & 31846 & 5 \\
\hline 14 & $\mathrm{~F}$ & 77 & 2 & & Quinagolide & $150 \mu \mathrm{g} / \mathrm{day}$ & 68 & 137189 & 35 \\
\hline 15 & $\mathrm{M}$ & 50 & 2 & Yes & Quinagolide & $300 \mu \mathrm{g} / \mathrm{day}$ & 101 & 31846 & 97 \\
\hline 16 & $\mathrm{M}$ & 67 & 2 & No & Quinagolide & $300 \mu \mathrm{g} / \mathrm{day}$ & 115 & 588679 & 42 \\
\hline 17 & $\mathrm{M}$ & 78 & 2 & Yes & Quinagolide & $300 \mu \mathrm{g} / \mathrm{day}$ & 187 & 95227 & 0 \\
\hline 18 & $\mathrm{~F}$ & 76 & 3 & Yes & Cabergoline & $2 \mathrm{mg} / \mathrm{week}$ & 72 & 164553 & 0 \\
\hline
\end{tabular}

knowledge on MRI results. The uptake of radioactivity in the pituitary area was compared with that in the left and right basal ganglia and the cerebral cortex. Absence of pituitary uptake was classified as grade 0 . Uptake in this region, which was higher than or equal to that observed for the basal ganglia, was classified as grade 3. Uptake in the pituitary region, which was less than in the basal ganglia but higher than in the cerebral cortex, was classified as grade 2 . Slight uptake, which was equal to or less than in the cerebral cortex, was classified as grade 1. Examples of grade 0-3 scans can be found in a previous publication (31). All the treated subjects underwent pituitary MRI at baseline, and 3-6 and 12 months following initiation of medical therapy and yearly thereafter. The method of volume calculation was based on the three axes of the tumor as previously described (20). In this method, the $x, y$, and $z$ radii were measured in the frontal, sagittal, and coronal planes respectively. Assuming a spherical volume, the formula $4 / 3 \pi r^{3}$ was used for volume calculation, $r$ being the mean of the $x, y$, and $z$ radii (20). Visual field examinations were performed at the same time points.

\section{Results}

Table 1 shows the distribution of ${ }^{123}$ I-epidepride uptake in the 85 patients. In two out of two patients with metastatic malignant macroprolactinomas (one of these patients was published as a case report, (36)) and in one out of two patients with metastatic malignant corticotrope tumors uptake in metastatic lesions could be demonstrated. Out of these 85 patients, 54 had NFPAs. Of these 54 NFPAs, 17 showed grade 0 uptake, 12 showed grade 1 uptake, 18 showed grade 2 uptake, and
7 showed grade 3 uptake of ${ }^{123}$ I-epidepride (Table 1 ). For a mean period of 89.7 months (range, 34-187 months), 18 patients ( 6 women, 12 men; mean age, 66 years; range, $32-86$ years) with NFPA were treated with DA agonists (either cabergoline (1-2 mg/week) or quinagolide (150-300 $\mu \mathrm{g} /$ day)). Grading of pituitary uptake of ${ }^{123}$ I-epidepride in these patients was as follows: grade 0 , four patients; grade 1 , three patients; grade 2, ten patients; and grade 3, one patient (Table 2). Patients were treated for 34-187 months with DA agonists (mean, 89.7 months; Table 2). In five patients, DA agonist therapy was started after pituitary surgery, one (patient 5 in Table 2) underwent surgery after medical therapy was initiated, because of the lack of significant tumor regression and a clinical significant threat of damage to neighboring structures. Tumor stabilization or shrinkage with DA agonist therapy was

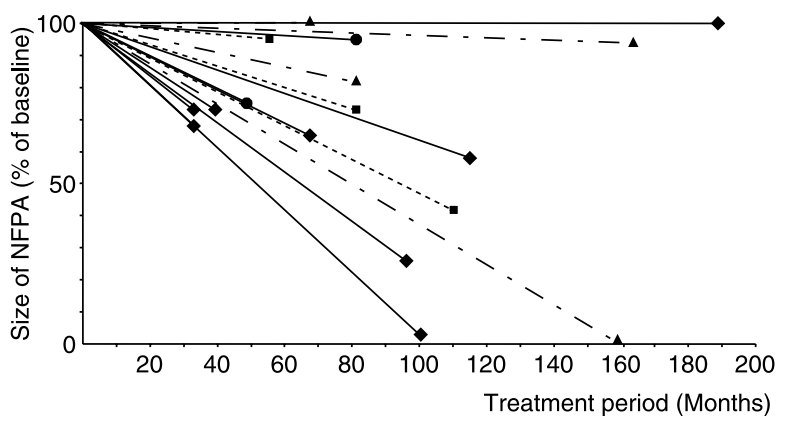

Figure 1 Change of tumor size, expressed as percentage of baseline size in 18 patients with clinically non-functioning pituitary macroadenomas (NFPAs) who have also undergone ${ }^{123}$ I-epidepride scintigraphy and have been treated with dopamine agonist therapy. $\boldsymbol{\Delta}$, grade 0 uptake of ${ }^{123}$-epidepride; $\mathbf{\square}$, grade 1 uptake of ${ }^{123}$ epidepride; $\mathbf{0}$, grade 2 uptake of ${ }^{123}$-epidepride; $\bullet$, grade 3 uptake of ${ }^{123}$ I-epidepride. 

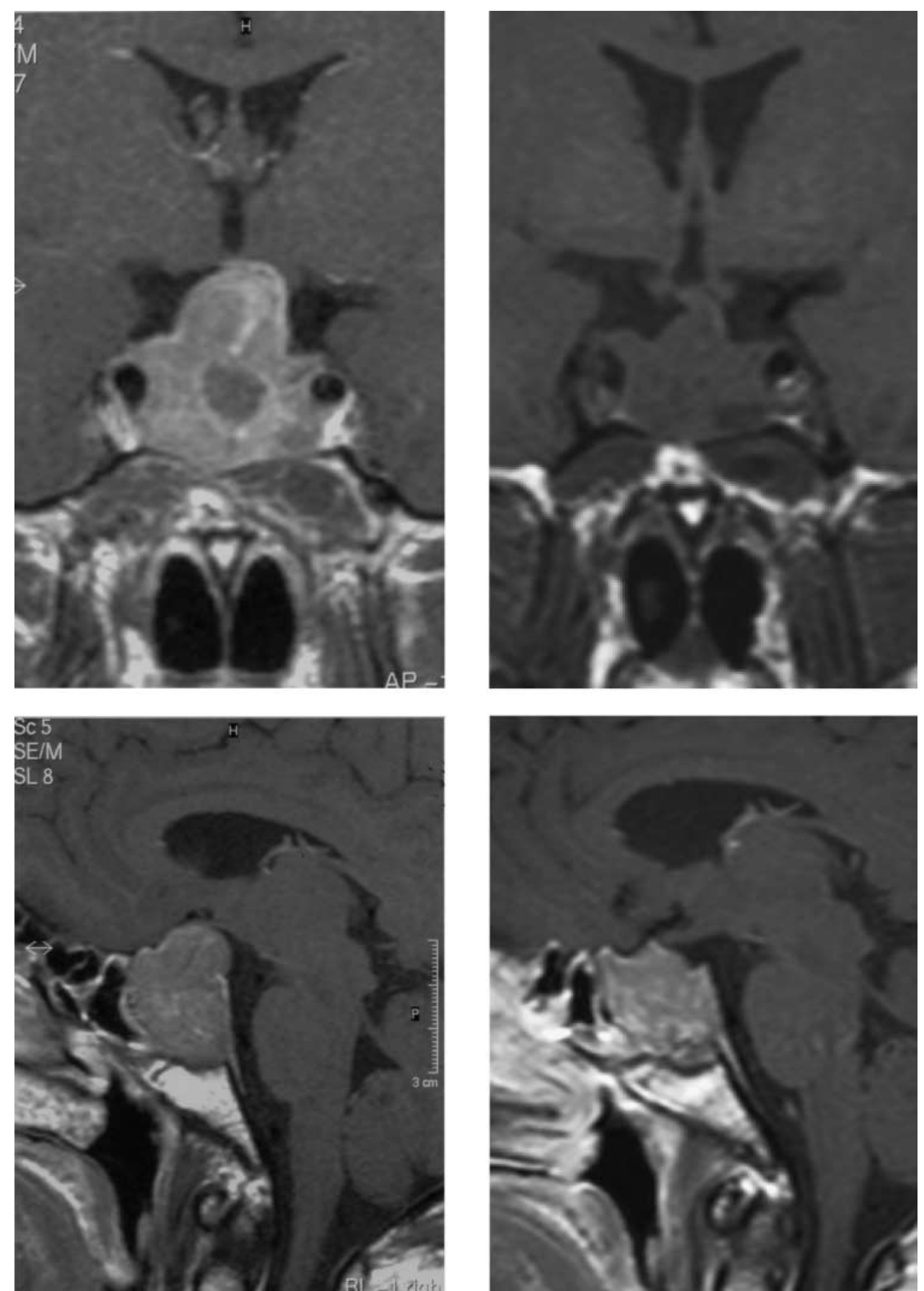

Figure 2 Magnetic resonance image in the coronal plane after administration of Gd-DTPA (top panels) and sagittal plane (bottom panels) of a histologically confirmed NFPA (in patient 10, Table 2) at baseline (left panels), and after 33 months (right panels) showing $32 \%$ tumor shrinkage with dopamine agonist therapy (cabergoline $1 \mathrm{mg} /$ week).

as follows: NFPAs with grade 0 uptake; mean \pm s.e.M., $31 \pm 20 \%$; range, 0-99\%; NFPAs with grade 1 uptake; mean \pm s.e.M., $30 \pm 15 \%$; range, 5-58\%; NFPAs with grade 2 uptake; mean \pm s.E.M., $36 \pm 9 \%$; range, $0-97 \%$; NFPA with grade 3 uptake, only one patient, $0 \%$; Table 2 , Figs $1-3$. One patient with a grade 0 tumor showed complete disappearance of the tumor (patient 2, Table 2), one patient with grade 1 tumor showed $58 \%$ shrinkage (patient 6, Table 2) and two patients with grade 2 tumors showed $74 \%$ and complete shrinkage respectively (patients 11 and 15 respectively, Table 2). When we considered a decrease in tumor size ranging from 0 to $20 \%$ as tumor stabilization and $>20 \%$ decrease in tumor size as true shrinkage, one out of four NFPAs with grade 1 uptake, two out of three NFPAs with grade 1 uptake, and eight out of ten NFPAs with grade 2 uptake showed 

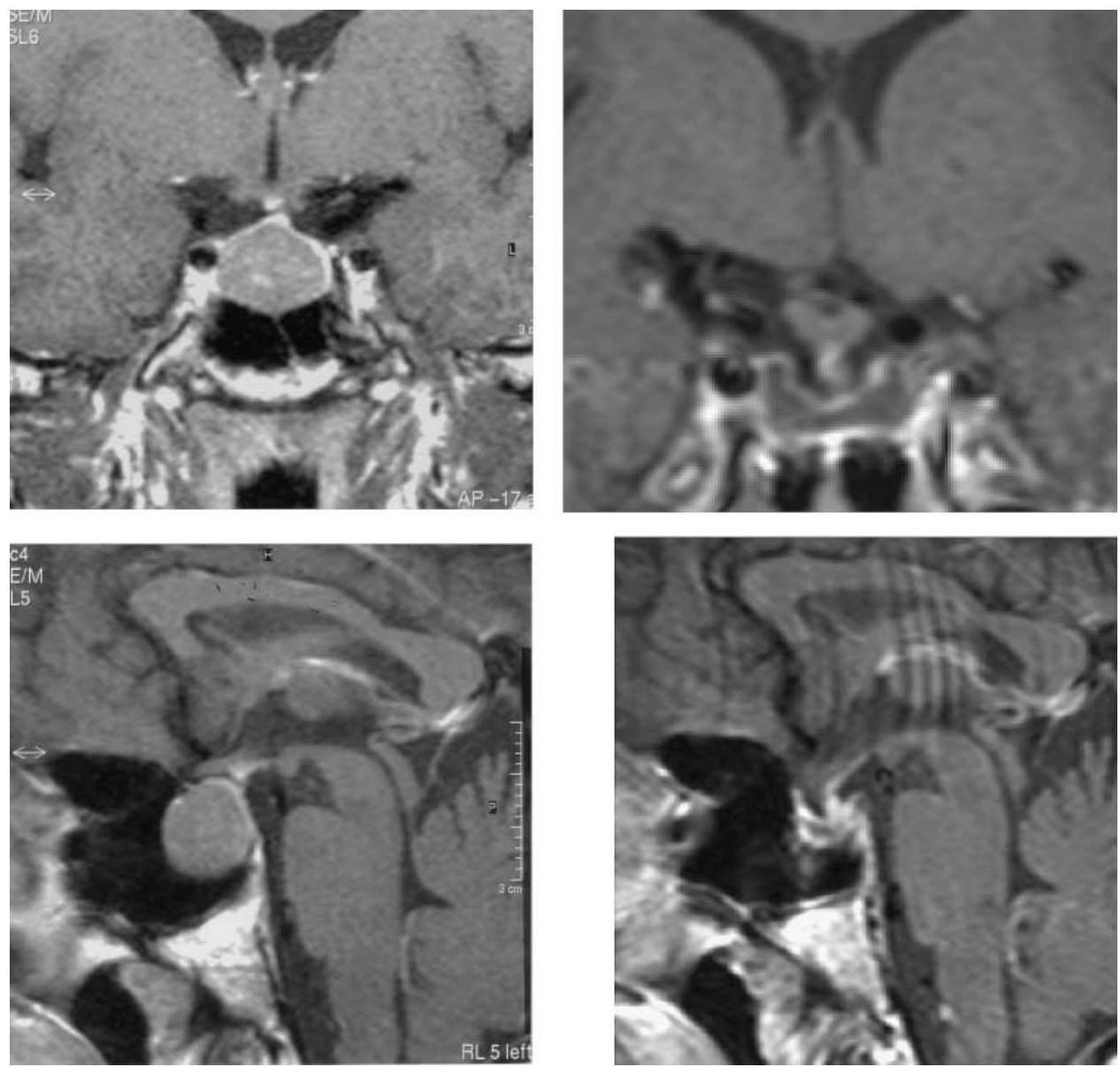

Figure 3 Magnetic resonance image in the coronal plane after administration of Gd-DTPA (top panels) and sagittal plane (bottom panels) of a NFPA (in patient 15, Table 2) at baseline (left panels), and after 100 months (right panels) showing $97 \%$ tumor shrinkage with dopamine agonist therapy (quinagolide $300 \mu \mathrm{g} / \mathrm{day}$ ).

tumor shrinkage. Despite differences in their affinities for the dopamine $\mathrm{D} 2$ and $\mathrm{D} 4$ receptor subtypes, there was no significant difference between cabergoline- and quinagolide-treated patients. DA agonist therapy resulted in a complete suppression of serum PRL levels to values below the detection limit in all patients (data not shown).

\section{Discussion}

NFPAs express functional membrane-bound dopamine receptors $(10,11,13,14,27,37,38)$. However, the effects of the DA agonist bromocriptine on reducing NFPA size has been disappointing, as most studies have shown only modest size reduction in a minority of treated tumors (12, $14,17,21,25)$. Therefore, bromocriptine therapy has not been advocated on a routine basis. Better, but still variable, results have been reported on the treatment with the nonergot DA agonist quinagolide and the specific DA agonist cabergoline $(20,23,26,27,34,35,39)$. The heterogeneity of responses to treatment has been attributed to the different pattern and level of expression of dopamine receptor subtypes in the individual tumors, as well as to possible alterations in the receptor-related signal transduction pathway $(10,27,38)$. In the present study, we were unable to demonstrate superiority of cabergoline over quinagolide or vice versa in the therapy of NFPAs. Greenman and co-workers have shown that tumor mass decreased or remained stable in $90 \%$ of patients in whom DA treatment was initiated upon detection of residual tumor on postoperative MRI (26). In $61 \%$ of patients with tumor remnant growth during the course of routine follow-up growth stabilized or decreased with this therapy (26). In contrast, tumor size remained stable in only 38\% and increased in the remaining $62 \%$ of untreated subjects (26). Pivonello and co-workers have shown significant tumor shrinkage in five out of nine patients treated with the DA agonist cabergoline for 12 months (27). The more prominent response was attained in patients whose tumors expressed the D2R short isoform (27). No useful clinical test presently exists that can predict the response to long-term dopaminergic treatment in NFPA patients. The present study shows that ${ }^{123}$ I-epidepride scintigraphy is generally not useful in this respect. However, using a $20 \%$ tumor decrease as cut-off for defining tumor shrinkage versus tumor stabilization a trend could be 
observed, especially NFPAs with grade 2 uptake demonstrated tumor shrinkage. However, ${ }^{123}$ I-epidepride scintigraphy might also still be useful in specific situations like those given in Table 1, for example, for discrimination of scar tissue from NFPA recurrence or residual NFPA, or the differential diagnosis between pituitary tumors and metastases. The present study reconfirms previous studies and shows that long-term (in this study, a mean follow-up of 7.5 years) tumor stabilization and shrinkage (in this study, a mean shrinkage of 30\%) can be attained using cabergoline or quinagolide therapy. In four patients, dramatic (58-100\%) tumor reduction, as can be seen in patients with macroprolactinomas (40-43) and some patients with Nelson's syndrome (44-46), could be observed. However, as pathology was lacking in two of these patients, it cannot be excluded that these patients had poorly functioning prolactinomas. This study reconfirms that quinagolide or cabergoline therapy can reduce the need for preventive postoperative radiotherapy, at least in some NFPA patients in whom there is evidence for remnant tumor growth, or they can either postpone or prevent pituitary surgery by preventing tumor enlargement. In patients with considerable co-morbidity or contraindications for operation, this therapy might also be tried. In the present series, we chose a maximum dose of $300 \mu \mathrm{g} /$ day quinagolide, or $2 \mathrm{mg} /$ week cabergoline, but it cannot be excluded that higher doses might have been (even) more effective. The clinical usefulness of ${ }^{123} \mathrm{I}-$ epidepride dopamine D2 receptor imaging for predicting the clinical efficacy of dopamine agonists in selected patients with NFPAs is limited.

\section{References}

1 Greenman Y \& Melmed S. Diagnosis and management of nonfunctioning pituitary tumors. Annual Review of Medicine $19964795-106$.

2 Snyder PJ. Gonadotroph cell pituitary adenomas. Endocrinology and Metabolism Clinics of North America 198716 755-764.

3 Snyder PJ. Gonadotroph cell adenomas of the pituitary. Endocrine Reviews $19856552-563$.

4 Ebersold MJ, Quast LM, Laws ER, Jr, Scheithauer B \& Randall RV. Long-term results in transsphenoidal removal of nonfunctioning pituitary adenomas. Journal of Neurosurgery $1986 \mathbf{6 4} 713-719$.

5 Comtois R, Beauregard H, Somma M, Serri O, Aris-Jilwan N \& Hardy J. The clinical and endocrine outcome to trans-sphenoidal microsurgery of nonsecreting pituitary adenomas. Cancer 199168 860-866.

6 Harris PE, Afshar F, Coates P, Doniach I, Wass JA, Besser GM \& Grossman A. The effects of transsphenoidal surgery on endocrine function and visual fields in patients with functionless pituitary tumours. Quarterly Journal of Medicine 198971 417-427.

7 Bradley KM, Adams CB, Potter CP, Wheeler DW, Anslow PJ \& Burke CW. An audit of selected patients with non-functioning pituitary adenoma treated by transsphenoidal surgery without irradiation. Clinical Endocrinology 199441 655-659.

8 Turner HE, Stratton IM, Byrne JV, Adams CB \& Wass JA. Audit of selected patients with nonfunctioning pituitary adenomas treated without irradiation - a follow-up study. Clinical Endocrinology $199951281-284$.
9 Snyder PJ, Fowble BF, Schatz NJ, Savino PJ \& Gennarelli TA. Hypopituitarism following radiation therapy of pituitary adenomas. American Journal of Medicine 198681 457-462.

10 An JJ, Cho SR, Jeong DW, Park KW, Ahn YS \& Baik JH. Antiproliferative effects and cell death mediated by two isoforms of dopamine D2 receptors in pituitary tumor cells. Molecular and Cellular Endocrinology 2003206 49-62.

11 Stefaneanu L, Kovacs K, Horvath E, Buchfelder M, Fahlbusch R \& Lancranjan L. Dopamine D2 receptor gene expression in human adenohypophysial adenomas. Endocrine 200114 329-336.

12 Lamberts SW, Verleun T, Oosterom R, Hofland L, van Ginkel LA, Loeber JG, van Vroonhoven CC, Stefanko SZ \& de Jong FH. The effects of bromocriptine, thyrotropin-releasing hormone, and gonadotropin-releasing hormone on hormone secretion by gonadotropin-secreting pituitary adenomas in vivo and in vitro. Journal of Clinical Endocrinology and Metabolism $198764524-530$.

13 Serri O, Marchisio AM, Collu R, Hardy J \& Somma M. Dopaminergic binding sites in human pituitary adenomas other than prolactinomas. Hormone Research 198419 97-102.

14 Bevan JS \& Burke CW. Non-functioning pituitary adenomas do not regress during bromocriptine therapy but possess membranebound dopamine receptors which bind bromocriptine. Clinical Endocrinology $1986 \mathbf{2 5} 561-572$.

15 Klibanski A, Shupnik MA, Bikkal HA, Black PM, Kliman B \& Zervas NT. Dopaminergic regulation of alpha-subunit secretion and messenger ribonucleic acid levels in alpha-secreting pituitary tumors. Journal of Clinical Endocrinology and Metabolism $1988 \mathbf{6 6}$ 96-102.

16 D'Emden MC \& Harrison LC. Rapid improvement in visual field defects following bromocriptine treatment of patients with nonfunctioning pituitary adenomas. Clinical Endocrinology 198625 697-702.

17 Vance ML, Ridgway EC \& Thorner MO. Follicle-stimulating hormone-and alpha-subunit-secreting pituitary tumor treated with bromocriptine. Journal of Clinical Endocrinology and Metabolism $1985 \mathbf{6 1}$ 580-584.

18 Grossman A, Ross R, Charlesworth M, Adams CB, Wass JA, Doniach I \& Besser GM. The effect of dopamine agonist therapy on large functionless pituitary tumours. Clinical Endocrinology 1985 22 679-686.

19 van Schaardenburg D, Roelfsema F, van Seters AP \& Vielvoye GJ. Bromocriptine therapy for non-functioning pituitary adenoma. Clinical Endocrinology 198930 475-484.

20 Nobels FR, de Herder WW, van Den Brink WM, Kwekkeboom DJ, Hofland LJ, Zuyderwijk J, de Jong FH \& Lamberts SW. Long-term treatment with the dopamine agonist quinagolide of patients with clinically non-functioning pituitary adenoma. European Journal of Endocrinology $2000143615-621$.

21 Bevan JS, Webster J, Burke CW \& Scanlon MF. Dopamine agonists and pituitary tumor shrinkage. Endocrine Reviews $199213220-240$.

22 Wollesen F, Andersen T \& Karle A. Size reduction of extrasellar pituitary tumors during bromocriptine treatment. Annals of Internal Medicine 198296 281-286.

23 Kwekkeboom DJ \& Lamberts SW. Long-term treatment with the dopamine agonist CV 205-502 of patients with a clinically nonfunctioning, gonadotroph, or alpha-subunit secreting pituitary adenoma. Clinical Endocrinology 199236 171-176.

24 de Bruin TW, Kwekkeboom DJ, van't Verlaat JW, Reubi JC, Krenning EP, Lamberts SW \& Croughs RJ. Clinically nonfunctioning pituitary adenoma and octreotide response to long term high dose treatment, and studies in vitro. Journal of Clinical Endocrinology and Metabolism 199275 1310-1317.

25 Renner U, Mojto J, Lange M, Muller OA, Von Werder K \& Stalla GK. Effect of bromocriptine and SMS 201-995 on growth of human somatotrophic and non-functioning pituitary adenoma cells in vitro. European Journal of Endocrinology 1994130 80-91.

26 Greenman Y, Tordjman K, Osher E, Veshchev I, Shenkerman G, Reider-Groswasser II, Segev Y, Ouaknine G \& Stern N. 
Postoperative treatment of clinically nonfunctioning pituitary adenomas with dopamine agonists decreases tumour remnant growth. Clinical Endocrinology 200563 39-44.

27 Pivonello R, Matrone C, Filippella M, Cavallo LM, Di Somma C, Cappabianca P, Colao A, Annunziato L \& Lombardi G. Dopamine receptor expression and function in clinically nonfunctioning pituitary tumors: comparison with the effectiveness of cabergoline treatment. Journal of Clinical Endocrinology and Metabolism 2004 89 1674-1683.

28 Pirker W, Brucke T, Riedl M, Clodi M, Luger A, Asenbaum S, Podreka I \& Deecke L. Iodine-123-IBZM-SPECT: studies in 15 patients with pituitary tumors. Journal of Neural Transmission. General Section $199497235-244$.

29 Pirker W, Riedl M, Luger A, Czech T, Rossler K, Asenbaum S, Angelberger P, Kornhuber J, Deecke L, Podreka I \& Brucke T. Dopamine D2 receptor imaging in pituitary adenomas using iodine-123-epidepride and SPECT. Journal of Nuclear Medicine 199637 1931-1937.

30 de Herder WW, Reijs AE, Kwekkeboom DJ, Hofland LJ, Nobels FR, Oei HY, Krenning EP \& Lamberts SW. In vivo imaging of pituitary tumours using a radiolabelled dopamine D2 receptor radioligand. Clinical Endocrinology $1996 \mathbf{4 5} 755-767$.

31 de Herder WW, Reijs AEM, de Swart J, Kaandorp Y, Lamberts SWJ, Krenning EP \& Kwekkeboom DJ. Comparison of iodine-123 epidepride and iodine-123 IBZM for dopamine D2 receptor imaging in clinically non-functioning pituitary macroadenomas and macroprolactinomas. European Journal of Nuclear Medicine 199926 46-50.

32 de Herder WW, Kwekkeboom DJ, Reijs AEM, Kooy PPM, Hofland LJ, Krenning EP \& Lamberts SW. Receptor scintigraphy with somatostatin analogues and dopamine antagonists of pituitary tumours. In Pituitary Adenomas. From Basic Research to Diagnosis and Therapy, pp 93-104. EdsK Von Werder \& R Fahlbusch, Amsterdam: Elsevier Science, BV, 1996.

33 Kwekkeboom DJ, de Herder WW \& Krenning EP. Receptor imaging in the diagnosis and treatment of pituitary tumors. Journal of Endocrinological Investigation 199922 80-88.

34 Colao A, Ferone D, Lastoria S, Cerbone G, Di Sarno A, Di Somma C, Lucci R \& Lombardi G. Hormone levels and tumour size response to quinagolide and cabergoline in patients with prolactin-secreting and clinically non-functioning pituitary adenomas: predictive value of pituitary scintigraphy with ${ }^{123}$ I-methoxybenzamide. Clinical Endocrinology 200052 437-445.

35 Ferone D, Lastoria S, Colao A, Varrella P, Cerbone G, Acampa W, Merola B, Salvatore M \& Lombardi G. Correlation of scintigraphic results using ${ }^{123}$ I-methoxybenzamide with hormone levels and tumor size response to quinagolide in patients with pituitary adenomas. Journal of Clinical Endocrinology and Metabolism 1998 $83248-252$.
36 Petrossians P, de Herder W, Kwekkeboom D, Lamberigts G, Stevenaert A \& Beckers A. Malignant prolactinoma discovered by D2 receptor imaging. Journal of Clinical Endocrinology and Metabolism $2000 \mathbf{8 5} 398-401$.

37 Renner U, Arzberger T, Pagotto U, Leimgruber S, Uhl E, Muller A, Lange M, Weindl A \& Stalla GK. Heterogeneous dopamine D2 receptor subtype messenger ribonucleic acid expression in clinically nonfunctioning pituitary adenomas. Journal of Clinical Endocrinology and Metabolism 199883 1368-1375.

38 Lania A, Reza-Elahi F, Gil-del-Alamo P, Saccomanno K, Mantovani S \& Spada A. Abnormal transduction of dopamine signal in human nonfunctioning pituitary adenomas. Journal of Endocrinological Investigation $1995 \mathbf{1 8} 265-270$.

39 Pivonello R, Ferone D, de Herder WW, Kros JM, De Caro ML, Arvigo M, Annunziato L, Lombardi G, Colao A, Hofland LJ \& Lamberts SW. Dopamine receptor expression and function in corticotroph pituitary tumors. Journal of Clinical Endocrinology and Metabolism $2004892452-2462$.

40 Ivan G, Szigeti-Csucs N, Olah M, Nagy GM \& Goth MI. Treatment of pituitary tumors: dopamine agonists. Endocrine 200528 101-110.

41 Colao A, Di Sarno A, Cappabianca P, Di Somma C, Pivonello R \& Lombardi G. Withdrawal of long-term cabergoline therapy for tumoral and nontumoral hyperprolactinemia. New England Journal of Medicine $20033492023-2033$.

42 Molitch ME. Medical management of prolactin-secreting pituitary adenomas. Pituitary 20025 55-65.

43 Pinzone JJ, Katznelson L, Danila DC, Pauler DK, Miller CS \& Klibanski A. Primary medical therapy of micro-and macroprolactinomas in men. Journal of Clinical Endocrinology and Metabolism 200085 3053-3057.

44 Casulari LA, Naves LA, Mello PA, Pereira NA \& Papadia C. Nelson's syndrome: complete remission with cabergoline but not with bromocriptine or cyproheptadine treatment. Hormone Research 200462 300-305.

45 Petrossians P, Ronci N, Valdes-Socin H, Kalife A, Stevenaert A, Bloch B, Tabarin A \& Beckers A. ACTH silent adenoma shrinking under cabergoline. European Journal of Endocrinology $2001 \mathbf{1 4 4}$ 51-57.

46 Pivonello R, Faggiano A, Di Salle F, Filippella M, Lombardi G \& Colao A. Complete remission of Nelson's syndrome after 1-year treatment with cabergoline. Journal of Endocrinological Investigation 199922 860-865.

Received 16 June 2006

Accepted 29 August 2006 